\title{
A Gratuidade de Justiça no Novo Código de Processo Civil
}

\section{The Gratuitousness of Justice in the new Code of Civil Procedure}

\author{
José Eduardo Figueiredo de Andrade Martins ${ }^{1}$
}

\begin{abstract}
RESUMO:
O presente artigo trata dos institutos concernentes à gratuidade de justiça presentes no Código de Processo Civil de 2015. Para tanto, são esclarecidas inicialmente as distinções entre assistência jurídica, gratuidade de justiça e assistência judiciária a partir de uma retrospectiva histórica do direito brasileiro. Em seguida, é realizada uma comparação entre a Lei n ${ }^{\circ}$ 1.060/50 e o Código de Processo Civil, apontando se há ainda utilidade daquela no ordenamento jurídico pátrio. Então, são analisados os artigos 98 a 102 do Código de Processo Civil e a jurisprudência do Superior Tribunal de Justiça consolidada sobre o tema, além de apontar interpretações e críticas que inevitavelmente surgirão no cotidiano forense.
\end{abstract}

\section{PALAVRAS-CHAVE:}

Gratuidade de justiça; assistência judiciária; assistência jurídica.

\begin{abstract}
:
This article deals with the institutes regarding the gratuitousness of justice present in the Code of Civil Procedure of 2015. For this, the distinctions between legal assistance, gratuitousness of justice and legal aid are clarified initially, starting from a historical retrospective of Brazilian law. Then, a comparison is made between Law No. 1,060/50 and the Code of Civil Procedure, indicating if there is still use of that in the brazillian legal system. Then, articles 98 to 102 of the Code of Civil Procedure and the jurisprudence of the Supreme Court of Justice on the subject are analyzed, as well as to point out interpretations and critiques that will inevitably arise in everyday forensics.
\end{abstract}

\section{KEYWORDS:}

Gratuitousness of justice; judicial assistance; legal assistance.

\footnotetext{
${ }^{1}$ Doutor e mestre em Direito Civil pela Universidade de São Paulo. Especialista em Direito Constitucional pela Pontifícia Universidade Católica de São Paulo. Participante do Summer Institute in Law and Economics da Faculdade de Direito da Universidade de Chicago. Bacharel em Direito pela Pontifícia Universidade Católica de Campinas. Professor dos cursos de graduação em Direito e pós-graduação lato sensu em Direito Tributário da Pontifícia Universidade Católica de Campinas. Advogado e consultor jurídico.
} 


\section{INTRODUÇÃO}

O tema da gratuidade de justiça, embora não seja recente, nunca deixou de ser polêmico no Brasil. Historicamente a legislação nunca o tratou satisfatoriamente, cabendo à doutrina e à jurisprudência preencher as lacunas conforme o surgimento dos casos concretos. Com o advento do Código de Processo Civil de 2015, todavia, parece que finalmente o ordenamento jurídico brasileiro terá normas que propiciarão uma maior segurança e estabilidade neste tópico, dedicando toda uma seção para o seu tratamento.

Neste estudo pretende-se, em um primeiro momento, resgatar as principais normas jurídicas que abordaram a gratuidade de justiça para mostrar que a confusão entre ela, a assistência judiciária e assistência jurídica tem origem histórica e legislativa. Com isso, será possível evidenciar que são conceitos distintos e importantes para a composição do devido acesso à justiça.

Fixados tais conceitos basilares, será feito um estudo comparativo e crítico entre a Lei $n^{\circ}$ 1.060/50 e o Código de Processo Civil, procurando demonstrar que não obstante aquela ainda tenha se mantido vigente, seu conteúdo é em certas passagens ou se tornará inócuo em breve. Será demonstrado, portanto, que prevalecerão as disposições do Código de Processo Civil.

A seguir será feita uma análise crítica das normas do diploma processual civil, pretendendo demonstrar o que se considera o melhor exercício hermenêutico e apontar possíveis problemas que surgirão no cotidiano forense e as soluções consideradas pertinentes conforme a intenção legislativa e o funcionamento do sistema jurídico brasileiro. Serão considerados, ainda, os entendimentos já consolidados pelo Superior Tribunal de Justiça e Supremo Tribunal Federal para reforço dos argumentos expostos e demonstração da pluralidade de situações que podem surgir além da capacidade criativa do legislador. 


\section{DESENVOLVIMENTO HISTÓRICO BRASILEIRO DOS CONCEITOS DE GRATUIDADE DE JUSTIÇA， ASSISTÊNCIA JUDICIÁRIA E ASSISTÊNCIA JURÍDICA}

A confusão entre o benefício da gratuidade de justiça, a assistência judiciária e a assistência jurídica não são novas. Desde a Constituição de 1934 se nota certa dificuldade dentre os juristas para diferenciar as três modalidades, chegando ao ponto de por muitas vezes serem tratados como se sinônimos fossem. Esta Carta Magna dispõe no artigo 113, item 32 que a União e os Estados concederão aos necessitados assistência judiciária, criando para órgãos especiais assegurando a isenção de emolumentos, custas, taxas e selos. Nota-se, portanto, que para a norma constitucional a gratuidade de justiça está contida na assistência judiciária.

A Constituição de 1937, outorgada por Getúlio Vargas, em nada menciona qualquer benefício para os necessitados no que concerne a assistência judiciária ou gratuidade de justiça, talvez em razão do momento de distensão entre os Poderes. No entanto, não significa que elas deixaram de existir, mas que simplesmente deixaram de ser consideradas um direito individual fundamental a ponto de serem postas no texto constitucional ${ }^{2}$.

Pontes de Miranda ${ }^{3}$, ao comentar o Código de Processo Civil de 1939, destaca que a assistência judiciária tem relação com a organização Estatal ou paraestatal que fornece aos necessitados serviços de um profissional habilitado para a prática de atos forenses. Benefício da gratuidade de justiça, por sua vez, diz respeito ao direito à dispensa das despesas judiciais, como as custas, despesas processuais e honorários advocatícios estipulados por decisão judicial.

É injusto, todavia, responsabilizar o Código de Processo Civil de 1939 pela confusão. Afinal, o artigo 68 é bastante claro ao conceder o benefício da gratuidade de justiça para custas, despesas e honorários de advogado. Menção a um advogado fornecido pelo Estado somente consta no parágrafo único, mas como efetivação da assistência judiciária e se a própria parte não constituir um.

\footnotetext{
${ }^{2}$ LIMA, Frederico Rodrigues Viana de. Defensoria Pública. Salvador: Juspodivm, 2010. p. 17-18.

${ }^{3}$ Cf. MIRANDA, Francisco Cavalcanti Pontes de. Comentários ao Código de Processo Civil: tomo I. Rio de Janeiro: Forense, 1958.
} 
A Constituição Federal de 1946, em seu artigo 141, §35, garante aos necessitados assistência judiciária pelo Poder Público na forma da lei, restando silente acerca dos benefícios da gratuidade de justiça. A regulamentação veio pela Lei $n^{\circ} 1.060 / 50$, a chamada Lei da Assistência Judiciária.

E esta parece ser a culpada pela histórica confusão ${ }^{4}$ Em seu artigo $3^{\circ}$ dispôs que a assistência judiciária compreende a isenção sobre custas, despesas processuais e honorários de advogado. Com isso, os conceitos tão bem delimitados pela doutrina autenticamente se misturaram por força legislativa, causando enorme perplexidade entre os juristas.

A Constituição Federal de 1967 manteve a redação da Constituição anterior no artigo 150, §32. O mesmo ocorreu na Constituição de 1969 no artigo 153, §32.

Anos depois, com o advento da Constituição Federal de 1988, mais um conceito foi introduzido no ordenamento jurídico: a assistência jurídica. O inciso LXXIV do artigo $5^{\circ}$ dispõe que o Estado prestará assistência jurídica integral e gratuita aos que comprovarem insuficiência de recursos.

A assistência jurídica, embora tenha surgido posteriormente no nosso sistema, deve ser considerada gênero da qual fazem parte as espécies assistência judiciária e justiça gratuita. Conceitualmente, assistência jurídica compreende não só a assistência judiciária, isto é, atos próprios de estar em juízo, mas também a gratuidade das despesas judiciais e a orientação préjudiciária ou extrajudicial ${ }^{5}$.

Portanto, gratuidade de justiça é a isenção de pagamento das custas e despesas processuais e honorários de advogado. Assistência judiciária, por sua vez, é o auxílio prestado pelo Estado ao necessitado em atos judiciais. Assistência jurídica, gênero das espécies anteriores, envolve também a orientação extrajudicial daquele tido como necessitado na forma da lei.

\footnotetext{
${ }^{4}$ ESTEVES, Diogo; SILVA, Franklyn Roger Alves. Princípios Institucionais da Defensoria Pública. Rio de Janeiro: Forense, 2014. p. 94; GIANNAKOS, Angelo Maraninchi. Assistência Judiciária no Direito Brasileiro. Porto Alegre: Livraria do Advogado, 2008. p. 22-23.

${ }^{5}$ BARBOSA, Ruy Pereira. Assistência jurídica. Rio de Janeiro: Forense, 1998. p. 62.
} 
As assistências jurídica e judiciária devem ser realizadas por meio de aparato Estatal ou de particulares em convênio com o Estado, que indicará advogados para a defesa dos interesses dos necessitados. Para tanto, atualmente no Brasil está à disposição os serviços da Defensoria Pública e dos advogados particulares conveniados a esta por meio da Ordem dos Advogados do Brasil ${ }^{6}$.

Ainda que haja definição conceitual precisa na teoria, parece que o legislador não se atentou devidamente a isto. Para trazer alguns exemplos, o artigo 56 da Lei $n^{\circ}$ 9.099/95, (Lei dos Juizados Especiais) trata assistência judiciária como sinônimo dos órgãos que realizam esta atividade, pois diz que deverá ser implantado o serviço de assistência judiciária com a instituição dos Juizados Especiais. A Lei n 11.340/06 (Lei Maria da Penha), em seu artigo 28, garante a todas as mulheres em situação de violência doméstica e familiar o acesso aos serviços de "Assistência Judiciária Gratuita" - em letras maiúsculas - como se órgão Estatal fosse. A Lei $\mathrm{n}^{\circ} 11.636 / 07$, que trata das custas judiciais no âmbito do Superior Tribunal de Justiça, em seu artigo 13 menciona a assistência judiciária como sinônimo de gratuidade de justiça.

Como o próprio legislador se confunde nas expressões, inevitavelmente a jurisprudência brasileira também as utilizou livremente, sem o devido cuidado e precisão técnica. Os exemplos são inúmeros, inclusive no Superior Tribunal de Justiça ${ }^{7}$ e no Supremo Tribunal Federal ${ }^{8}$.

Finalmente, com o advento do Código de Processo Civil em 2015, a expressão "gratuidade de justiça" foi utilizada corretamente e muitos artigos da Lei $\mathrm{n}^{\circ}$ 1.060/50 foram revogados, consertando parte da confusão de significados que imperou por décadas na

\footnotetext{
${ }^{6}$ Existem quatro modelos de assistência judiciária gratuita: pro bono, judicare, salaried staff model e misto (híbrido). No modelo pro bono, advogados particulares prestam a assistência judiciária gratuita sem nenhuma espécie de contraprestação Estatal. No judicare, advogados particulares que prestam assistência judiciária gratuita são remunerados pelo Estado. No salaried staff model, o Estado remunera agentes públicos para a realização da assistência judiciária gratuita. Por fim, no modelo misto (híbrido) há a combinação de alguns ou todos os modelos anteriores (LIMA, Frederico Rodrigues Viana de. Defensoria Pública. Salvador: Juspodivm, 2010. p. 55-58). Atualmente no Brasil prevalece o modelo misto, pois existe a advocacia pro bono prevista no artigo 30 do Código de Ética e Disciplina da Ordem dos Advogados do Brasil, o judicare com o convênio da Ordem dos Advogados com a Defensoria Pública e o salaried staff model pela existência da própria Defensoria Pública.

${ }^{7}$ BRASIL. Superior Tribunal de Justiça, $1^{\text {a }}$ Turma. Recurso Especial no $1.082 .376 / R N$. Rel. Min. Luiz Fux, votação unânime, j. 17/02/2009.

${ }^{8}$ BRASIL. Supremo Tribunal Federal, $1^{a}$ Turma. Agravo Regimental no Agravo de Instrumento $n^{\circ}$ 580.880. Rel. Min. Menezes Direito, votação unânime, j. 07/04/2009; BRASIL. Supremo Tribunal Federal, $2^{\mathrm{a}}$ Turma. Agravo Regimental no Recurso Extraordinário nº 550.202. Rel. Min. Cezar Peluso, votação unânime, j. 11/03/2008.
} 
legislação brasileira. Entretanto, com alguns dispositivos ainda vigentes, ainda há utilidade da Lei $\mathrm{n}^{\mathrm{o}} 1.060 / 50$ no ordenamento jurídico brasileiro?

\section{A LEI N N $^{\circ}$ 1.060/50 EM FACE DAS DISPOSIÇÕES DO CÓDIGO DE PROCESSO CIVIL}

O artigo 1.072, inciso III do Código de Processo Civil revogou os artigos $2^{\circ}, 3^{\circ}, 4^{\circ}, 6^{\circ}$, $7^{\circ}, 11,12$ e 17 da Lei $n^{\circ}$ 1.060/50. Como referida lei só possui 19 artigos, é nítido que quase todos os seus dispositivos deixaram de fazer parte do ordenamento jurídico brasileiro. No entanto, ainda subsistem os artigos $1^{\circ}, 5^{\circ}, 8^{\circ}, 9^{\circ}, 10,13,14,15,16$ e 18 que, adianta-se, alguns deles ainda têm alguma diminuta aplicabilidade.

O artigo $1^{\circ}$ da Lei $n^{\circ} 1.060 / 50$ já pouco acrescentava desde o advento da Constituição Federal de 1988, haja vista que o comando constitucional é muito mais amplo. Sendo assim, sua manutenção é obsoleta para o direito brasileiro.

O caput do artigo $5^{\circ}$ da Lei $\mathrm{n}^{\circ} 1.060 / 50$ não pode mais ser admitido como válido no sistema jurídico pátrio. Aduz o dispositivo que o juiz, se não tiver fundadas razões para indeferir o pedido de gratuidade de justiça, deverá julgá-lo de plano, motivando ou não o deferimento dentro do prazo de 72 horas. A primeira parte do dispositivo, pela regra cronológica de resolução de antinomias já está superado, tendo em vista que o artigo 99, parágrafo $2^{\circ}$ do Código de Processo Civil regulamenta a matéria. Ademais, o prazo de 72 horas já era e continua sendo incompatível com a realidade forense atual, não tendo mais razão de existir. A segunda parte do artigo, por sua vez, não só também está superado pela mesma norma do diploma processual como contém regra inconstitucional ao permitir o indeferimento da gratuidade sem motivação. O artigo 93, inciso IX da Constituição Federal obriga que todas as decisões sejam fundamentadas e o artigo 489, parágrafo $1^{\circ}$, do Código de Processo Civil explicita como esta deve ser realizada.

Os parágrafos $1^{\circ}$ a $4^{\circ}$ do artigo $5^{\circ}$ da Lei $n^{\circ} 1.060 / 50$ tratam a respeito do tema da advocacia dativa, isto é, da assistência judiciária realizada pelo próprio Estado ou por 
advogados particulares indicados pela Ordem dos Advogados do Brasil. Na falta de um órgão Estatal de assistência e se não houver subseção da Ordem dos Advogados do Brasil na localidade, é permitido ao magistrado nomear um advogado para o patrocínio da causa. Tais regras não estão efetivamente revogadas, mas sofrem de uma progressiva inconstitucionalidade ${ }^{9}$, conforme o avanço da instalação das Defensorias Públicas nos entes federativos brasileiros.

De acordo com o que preconiza o artigo 98 dos Atos das Disposições Constitucionais Transitórias, no prazo de oito anos, ou seja, até o ano de 2022 - já que referido dispositivo foi incluído pela Emenda Constitucional no 80/2014 -, a União, Estados e Distrito Federal deverão possuir defensores públicos em todas as unidades jurisdicionais, em proporcionalidade com a efetiva demanda pelo seu serviço e à respectiva população. Sendo assim, enquanto não houver Defensoria Pública instalada em determinado local, valerá o disposto nos supracitados parágrafos; com a sua instalação, prevalecerá os dispositivos concernentes à Defensoria Pública presentes na Lei Complementar nº 80/94 e na legislação estadual.

O parágrafo $5^{\circ}$ do artigo $5^{\circ}$ da Lei $n^{\circ} 1.060 / 50$ preconiza que o Defensor Público, ou quem exerça cargo equivalente, terá a prerrogativa de ser intimado pessoalmente de todos os atos do processo e os prazos serão contados em dobro. A regra não existe mais razão de ser, pois diz o mesmo que já está previsto no artigo 44, I, 89, I e 128, I da Lei Complementar no 80/94, para os Defensores Públicos da União, do Distrito Federal e dos Territórios e dos Estados, respectivamente ${ }^{10}$. Ademais, a disciplina é repetida no artigo 186 do Código de

\footnotetext{
${ }^{9}$ A inconstitucionalidade progressiva já foi declarada mais de uma vez pelo Supremo Tribunal Federal. Para ilustrar hipótese relacionada ao tema deste estudo, nos Recursos Extraordinários no 135.328 e 147.776, restou decidido que o artigo 68 do Código de Processo Penal sofre de inconstitucionalidade progressiva à medida que as Defensorias Públicas são instaladas, haja vista que a propositura da chamada ação civil ex delicto para os considerados pobres é de competência - determinada pela Constituição Federal - da Defensoria Pública, ao contrário do que afirma o dispositivo que é do Ministério Público. A razão da diferença de regulamentação é que o dispositivo processual penal é anterior à Constituição, em contexto histórico que não se cogitava de um órgão independente para o atendimento de pessoas carentes. O caso, portanto, seria de não recepção do dispositivo legal pela Constituição Federal, mas expulsá-lo do ordenamento jurídico seria muito mais prejudicial para a sociedade, por de fato não haver quem promovesse a ação em locais que não houvesse a Defensoria Pública, do que mantêlo e considerá-lo inconstitucional apenas onde a Defensoria Pública estivesse instalada.

${ }^{10} \mathrm{O}$ prazo em dobro para a Defensoria Pública só tem sua validade questionada no processo penal. De fato, haveria uma violação ao princípio da isonomia e do devido processo legal se a Defensoria Pública tivesse direito à contagem dobrada do przo e o Ministério Público não. O problema chegou ao Supremo Tribunal Federal que decidiu a regra é constitucional até que a Defensoria Pública efetivamente se instale, isto é, que concretamente esteja organizada com estrutura "que lhe possibilite atuar em posição de igualdade com o Ministério Público, tornando-se inconstitucional, porém, quando essa circunstância de fato não mais se verificar” (BRASIL. Supremo
} 
Processo Civil. Posto que seja anterior às referidas normas jurídicas, a revogação expressa do parágrafo em nada prejudicaria as prerrogativas.

Um simples exercício hermenêutico já esclarece que o artigo $8^{\circ}$ da Lei $n^{\circ} 1.060 / 50$ não encontra mais espaço no ordenamento jurídico brasileiro. Aduz o dispositivo que, ocorrendo circunstâncias mencionadas no artigo anterior, o juiz poderá de ofício decretar a revogação dos benefícios, ouvida a parte interessada dentro de quarenta e oito horas improrrogáveis.

O primeiro nítido problema é a remissão a um artigo de lei revogado pelo artigo 1.072, inciso III do Código de Processo Civil, o que já inviabiliza a sua aplicação. O segundo que a revogação ex officio pelo magistrado sem oportunidade de manifestação da parte viola o princípio da não surpresa expressamente adotado pelo artigo $9^{\circ}$ do Código de Processo Civil, que veda a tomada de decisão sem a oitiva prévia da parte prejudicada. $O$ terceiro é que o artigo 100 do Código de Processo Civil disciplina justamente as situações que eram previstas no revogado artigo $7^{\circ}$ e no artigo $8^{\circ}$ da Lei $n^{\circ} 1.060 / 50$. Com isso, há também uma evidente revogação tácita em razão a aplicação da regra cronológica de solução de antinomias.

Já o artigo $9^{\circ}$ da Lei $\mathrm{n}^{\circ}$ 1.060/50 tem melhor sorte, pois não existe dispositivo correspondente no Código de Processo Civil, ainda que seja possível extrair de uma leitura sistemática e teleológica dos artigos 98, parágrafo primeiro, inciso VIII, 99, parágrafo $5^{\circ}$ e 101 , parágrafo $1^{\circ}$. No artigo 98, parágrafo primeiro, inciso VIII, há a previsão de gratuidade para os depósitos previstos em lei para interposição de recurso e de outros atos processuais inerentes ao exercício da ampla defesa e do contraditório. Desta regra, já se verifica que se há continuidade no processo e havendo concessão do benefício, ele deverá abarcar a fase recursal. No artigo 99, parágrafo $5^{\circ}$, ao negar a extensão ao advogado do benefício no caso de recurso somente sobre os honorários de sucumbência, o dispositivo dá a entender que para o recurso a gratuidade de justiça está mantida. Igualmente, o artigo 101, parágrafo $1^{\circ}$ dispensa o recolhimento de custas até a decisão do relator sobre recurso de agravo de instrumento contra o indeferimento do pedido de gratuidade de justiça, o que evidencia também que o benefício acompanha a marcha processual.

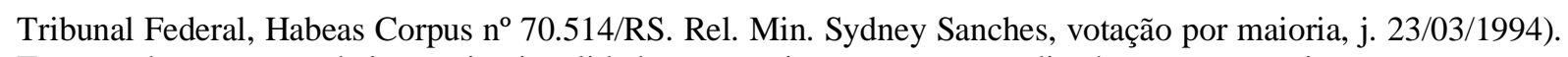
Trata-se de outro caso de inconstitucionalidade progressiva, consoante explicado na nota anterior. 
O supracitado dispositivo da Lei $\mathrm{n}^{\circ} 1.060 / 50$, por sua vez, expressamente mantém o benefício a todos os atos do processo até decisão final do litígio e em todas as instâncias. $\mathrm{O}$ Superior Tribunal de Justiça, inclusive, invocou-o no julgamento de um recurso para destacar a eficácia da decisão que defere o benefício em todas as instâncias e graus de jurisdição ${ }^{11}$. A regra só comportaria exceções, que não a prejudicam em uma leitura conjunta, caso haja concessão de gratuidade para atos processuais específicos, consoante artigo 98 , parágrafo $5^{\circ}$ do Código de Processo Civil.

A regra do artigo $10^{\circ}$ da Lei $n^{\circ} 1.060 / 50$, que trata da impossibilidade de transmissão do benefício da gratuidade de justiça não tem mais razão de existir, tendo em vista que o artigo 99, parágrafo $6^{\circ}$ do Código de Processo Civil tratou do tema. A razão de o legislador ter mantido este dispositivo é uma incógnita.

Mesmo destino acompanha o artigo 13 da Lei $\mathrm{n}^{\circ}$ 1.060/50 que trata da concessão parcial de gratuidade de justiça, nunca posto em prática. O Código de Processo Civil tratou da matéria no artigo 98, parágrafo $5^{\circ}$ e com maior detalhamento, não havendo dúvidas acerca da revogação tácita do dispositivo da Lei ${ }^{\circ} 1.060 / 50$.

Os artigos 14 e 15 da Lei $\mathrm{n}^{\circ}$ 1.060/50 tratam dos casos de recusa e impedimento do advogado dativo para o seu múnus público. Assim, enquanto ainda a advocacia dativa existir, estes artigos terão utilidade prática.

Acerca do artigo 16, ele parece recair na mesma situação dos antecedentes por tratar da exibição em audiência do instrumento de mandato pelo assistido pelo advogado dativo. Todavia, é de se ressaltar que o Superior Tribunal de Justiça já decidiu que a Defensoria Pública se enquadra no parágrafo único deste dispositivo, não sendo exigida dela o instrumento de mandato $^{12}$.

Finalmente, o artigo 18 da Lei $n^{\circ} 1.060 / 50$ está tacitamente revogado pelo artigo $3^{\circ}$, parágrafo $2^{\circ}$ da Lei ${ }^{\circ}$ 8.906/94 (Estatuto da Ordem dos Advogados do Brasil). A assistência judiciária não pode ser realizada por qualquer acadêmico de Direito, independentemente do

\footnotetext{
${ }^{11}$ BRASIL. Superior Tribunal de Justiça, Corte Especial. Embargos de Divergência em Agravo em Recurso Especial no 86.915/SP. Rel. Min. Raul Araújo, votação unânime, j. 26/02/2015.

12 BRASIL. Superior Tribunal de Justiça, $1^{a}$ Turma. Agravo Interno no Agravo em Recurso Especial $\mathrm{n}^{\circ}$ 525.359/MS. Rel. Min. Gurgel de Faria, votação unânime, j. 06/02/2018.
} 
período que esteja cursando, salvo se estiver regularmente inscrito, em conformidade com o regimento geral e em conjunto com advogado e sob a responsabilidade deste, na modalidade de estágio.

Com isso, nota-se que, apesar de a Lei n ${ }^{\circ} 1.060 / 50$ estar ainda vigente, seus dias estão contados. A inconstitucionalidade progressiva dos dispositivos restantes atinentes à advocacia dativa e os demais que já estão presentes, expressa ou implicitamente, no Código de Processo Civil, fazem com que as atenções se voltem quase que completamente a este. E é o que será feito de agora em diante neste estudo.

\section{O BENEFICIÁRIO DA GRATUIDADE DE JUSTIÇA}

Conforme se extrai do artigo 98, caput, do Código de Processo Civil, o beneficiário da gratuidade de justiça é a pessoa natural ou jurídica, brasileira ou estrangeira, com insuficiência de recursos para pagar as custas, as despesas processuais e os honorários advocatícios. O dispositivo põe fim a uma histórica polêmica se pessoa jurídica poderia pleitear o benefício.

Dentre os posicionamentos outrora existentes na doutrina e na jurisprudência, haviam aqueles que, com base em uma literal interpretação da Lei $\mathrm{n}^{\circ} 1.060 / 50$, defendiam que apenas as pessoas físicas poderiam estar isentas das despesas judiciais. Os artigos $2^{\circ}$ e $4^{\circ}$, hoje revogados pelo Código de Processo Civil, dispunham que o gozo da assistência judiciária (sic) era destinado àqueles que não poderiam arcar com as despesas judiciais sem prejuízo próprio ou da família. Como somente as pessoas físicas podem ter família, logo estariam excluídas as pessoas jurídicas. Outros, em uma interpretação mais analítica dos dispositivos, compreendiam que a conjunção “ou”, de acordo com o nosso vernáculo, também poderia excluir a presença da família, o que faria com que as pessoas jurídicas estivessem igualmente contempladas. 
E ainda dentre os que admitiam que a pessoa jurídica poderia ser beneficiária havia divergência. Para alguns, apenas entidades filantrópicas, pias, beneficentes ou sem fins lucrativos. Outros, todas as pessoas jurídicas ${ }^{13}$.

Somente no ano de 2012 houve pacificação da matéria pelo Superior Tribunal de Justiça, o qual editou a súmula 481 que diz fazer "jus ao benefício da justiça gratuita a pessoa jurídica com ou sem fins lucrativos que demonstrar sua impossibilidade de arcar com os encargos processuais". No entanto, como se nota, há uma diferença de tratamento da pessoa física: enquanto esta tem presunção de veracidade na sua declaração de necessidade, a pessoa jurídica precisa provar esta condição, pois a presunção é a de que detém recursos capazes de viabilizar o seu ingresso em juízo, ainda que sem fins lucrativos.

A orientação jurisprudencial foi seguida pelo legislador. O artigo 99 , parágrafo $3^{\circ}$ do Código de Processo Civil disciplina que há uma presunção de veracidade na alegação de insuficiência de recursos deduzida exclusivamente por pessoa natural. A presunção não foi estendida para as pessoas jurídicas. Todavia, é iuris tantum, admitindo prova em contrário.

Inclusive, em razão de haver uma presunção relativa de veracidade na declaração de hipossuficiência, o Superior Tribunal de Justiça ${ }^{14}$ já se posicionou pela atipicidade da conduta daquele que a alega falsamente. Não há crime de falsidade ideológica (artigo 299 do Código Penal) ou de uso de documento falso (artigo 304 do Código Penal) quando a alegação é passível de comprovação posterior, seja por provocação da parte contrária, seja por aferição de ofício do magistrado. Somente o documento dotado de presunção absoluta ou que não estiver sujeito à confirmação pela parte interessada é que configura referidos crimes.

Outros entendimentos também se consolidaram ao longo do tempo acerca da pessoa jurídica. O Superior Tribunal de Justiça já se manifestou desfavoravelmente à concessão da gratuidade de justiça sob o único argumento de que houve decretação de liquidação extrajudicial ou falência ${ }^{15}$. Também não caberá a este Tribunal apreciar o recurso contra decisão

\footnotetext{
${ }^{13}$ DIDIER JR., Fredie; OLIVEIRA, Rafael. Benefício da justiça gratuita. Salvador: Juspodivm, 2008. p. 30.

${ }^{14}$ BRASIL. Superior Tribunal de Justiça, $6^{a}$ Turma. Habeas Corpus n ${ }^{\circ} 217.657 / S P$. Rel. Min. Vasco Della Giustina (Desembargador convocado do TJ/RS), votação unânime, j. 02/02/2012; BRASIL. Superior Tribunal de Justiça, $6^{a}$ Turma. Habeas Corpus $n^{\circ}$ 218.570/SP. Rel. Min. Maria Thereza de Assis Moura, votação unânime, j. $16 / 02 / 2012$.

15 BRASIL. Superior Tribunal de Justiça, $3^{\mathrm{a}}$ Turma. Agravo Interno no Agravo em Recurso Especial $\mathrm{n}^{\circ}$ 1.140.206/RS. Rel. Min. Ricardo Villas Bôas Cueva, votação unânime, j. 27/02/2018.
} 
que denega o benefício por envolver reapreciação do conjunto fático-probatório, violando a sua súmula $\mathrm{n}^{\mathrm{o}} 7^{16}$. Ainda, o espólio, mesmo não tendo personalidade jurídica, faz jus à gratuidade de justiça se constatada a modéstia do monte a ser transmitido e a extrema dificuldade de atendimento das despesas judiciais ${ }^{17}$.

Em consonância com a hermenêutica mais alinhada com os ditames constitucionais, não se admite que apenas os estrangeiros residentes no país tenham o direito à gratuidade de justiça, assim como restringia a redação do artigo $2^{\circ}$ da Lei $n^{\circ} 1.060 / 50$. A norma já era interpretada extensivamente antes $^{18}$ e agora o Código de Processo Civil eliminou definitivamente a inconstitucional restrição.

Hipótese interessante consiste em indagar se apenas pessoas pobres têm direito à gratuidade de justiça. Tanto a Constituição Federal quanto o Código de Processo Civil utilizam a expressão "com insuficiência de recursos" ao invés de pobres. Parece aí haver uma distinção importante: não precisa a pessoa ser necessariamente pobre para fazer jus ao benefício, mas diante de sua situação, ainda que transitória, não ter capacidade financeira de arcar com as despesas judiciais. Desse modo, parece-nos que mesmo uma pessoa rica, se tiver com seu patrimônio comprometido com despesas imprescindíveis (como com tratamentos de saúde, por exemplo) que obstaculizam o gasto judicial, poderá ser beneficiada pela gratuidade de justiça. No entanto, cada caso deve ser verificado com parcimônia e atenção para não se criar injustiças de conceder gratuidade para aqueles que podem arcar com as despesas se simplesmente se reeducarem financeiramente.

O direito à gratuidade de justiça concedido a uma das partes não é transferido para as demais. O artigo 99, parágrafo $6^{\circ}$ do Código de Processo Civil aduz que não há extensão do benefício aos litisconsortes ou sucessores do beneficiário se não houver expressamente manifestação neste sentido pelo magistrado. Assim, havendo pluralidade de autores ou réus, o deferimento do benefício será dado àquele que pleitear. E caso algum beneficiário faleça, o seu sucessor deverá pleitear para si o benefício também.

\footnotetext{
16 BRASIL. Superior Tribunal de Justiça, $3^{\mathrm{a}}$ Turma. Agravo Interno no Agravo em Recurso Especial $\mathrm{n}^{\circ}$ 1.131.308/RS. Rel. Min. Paulo de Tarso Sanseverino, votação unânime, j. 27/02/2018.

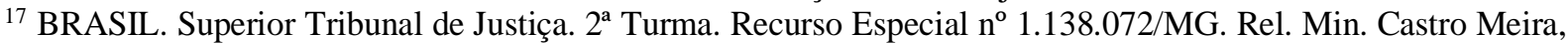
votação unânime, j. 01/03/2011.

${ }^{18}$ LIMA, Frederico Rodrigues Viana de. Defensoria Pública. Salvador: Juspodivm, 2010. p. 46-47.
} 
Outra regra que adotou orientação jurisprudencial anterior é a presente no artigo 99, parágrafo $4^{\mathrm{o}}$ do Código de Processo Civil. Não há impedimento à gratuidade de justiça a assistência realizada à parte por um advogado particular. O patrocínio da causa é independente da necessidade da parte, raciocínio este reforçado com a regulamentação pelo Código de Ética e Disciplina da Ordem dos Advogados do Brasil em 2015 no seu artigo 30 da advocacia pro bono. Com ela, se presta de forma gratuita, eventual e voluntária serviços jurídicos em favor de instituições sociais sem fins econômicos e aos seus assistidos, sempre que os beneficiários não dispuserem de recursos para a contratação de profissional e de pessoas naturais que, igualmente, não dispuserem de recursos para, sem prejuízo do próprio sustento, contratar advogado.

Pelos mesmos fundamentos dos parágrafos $4^{\circ}$ e $6^{\circ}$ é que o parágrafo $5^{\circ}$ do artigo 99 do Código de Processo Civil define que se o advogado recorrer pessoalmente contra decisão de determinação de seus honorários de sucumbência o benefício da justiça gratuita não será a ele estendido, dependendo de demonstração particular de sua necessidade.

Algumas regras estabelecidas pela jurisprudência do Superior Tribunal de Justiça, contudo, devem ser observadas quando se tratar de representação pela Defensoria Pública. Sendo pessoa jurídica ou física, não basta ter sido nomeado um defensor público para a defesa para atrair a gratuidade de justiça se tal ato é derivado de citação por edital em que a parte se quedou inerte. Assim, a citação ficta, por si só, não atrai a presunção de miserabilidade, devendo ser requerida ou comprovada nos autos ${ }^{19}$.

Conceder gratuidade de justiça, contudo, não significa afastamento da responsabilidade do beneficiário pelas custas judiciais decorrentes de sua sucumbência. Assim dispõe o artigo 98, parágrafo $2^{\circ}$ do Código de Processo Civil, que evidencia que a gratuidade de justiça concedida é um mero elemento acidental que obsta a eficácia do ato de cobrança das despesas judiciais.

De fato, o artigo 98, parágrafo $3^{\circ}$ do Código de Processo Civil diz que com a derrota do beneficiário as obrigações decorrentes desta sucumbência ficarão sob condição suspensiva de exigibilidade, podendo ser exigidas apenas nos próximos cinco anos após o trânsito em julgado da decisão que as certificou. E isto somente se o credor provar que deixou de existir a situação

19 BRASIL. Superior Tribunal de Justiça, $1^{\mathrm{a}}$ Turma. Agravo Regimental no Agravo em Recurso Especial $\mathrm{n}^{\circ}$ 556.355/MG. Rel. Min. Sérgio Kukina, votação unânime, j. 10/02/2015. 
de insuficiência de recursos que justificou a concessão de gratuidade. Passados os cincos anos - prazo este de natureza decadencial e não comportando, portanto, impedimentos, suspensões ou interrupções - não será mais possível cobrar do beneficiário o valor relativo às despesas judiciais.

Isto não significa, contudo, que o beneficiário está isento de adimplir de toda e qualquer verba decorrente da demanda. Além de obviamente estar obrigado a pagar o que foi formulado contra si na petição inicial, caso o beneficiário seja o réu, ou em reconvenção ou pedido contraposto, caso o beneficiário seja autor, se for condenado, também deverá arcar com as multas processuais que lhe sejam impostas (artigo 98, parágrafo $4^{\circ}$ do Código de Processo Civil). A justificativa é simples: a multa processual não é um pagamento ao Estado pelos serviços judiciários e demais despesas concernentes ao processo, mas uma penalidade imposta pelo juiz em razão do descumprimento de algum comando judicial.

\section{O OBJETO DA GRATUIDADE DE JUSTIÇA}

O parágrafo primeiro do artigo 98 do Código de Processo Civil traz um rol taxativo de valores que estão sujeitos à gratuidade de justiça. Alguns deles são novidades no nosso ordenamento jurídico (incisos VII e IX), outros mantêm o que já se entendia compreendido no benefício (incisos I, II e VIII) e outros tiveram alguns acréscimos que merecem destaque (incisos III, IV, V e VI).

O inciso I do supramencionado dispositivo admitem como gratuitas as taxas ou custas judiciais. Tratam-se de valores arrecadados pelo respectivo ente federativo como forma de contraprestação por um serviço prestado. Como exemplo, existem as despesas com a movimentação dos autos processuais no Tribunal, com diligências de oficiais de justiça, desarquivamento de autos, etc. Quando for taxa, imprescindível que seja instituída por lei, haja vista ter natureza de tributo ${ }^{20}$.

\footnotetext{
${ }^{20}$ A discussão acerca da natureza da despesa é importante porque o desrespeito à formalidade acarreta na inconstitucionalidade de sua cobrança. Caso relevante ocorreu no Tribunal de Justiça de São Paulo, em que um 
Os selos postais referidos no inciso II são as estampilhas adesivas ou fixas que se destinam à comprovação do pagamento da prestação de serviço postal. Assim como ocorria já na Lei $n^{\circ} 1.060 / 50$, também estão abrangidos no benefício da gratuidade de justiça em procedimentos judiciais que envolvam a comunicação por correio, como no caso de citações por carta, por exemplo.

O inciso III trata das despesas com publicação na imprensa oficial. A Lei nº 1.060/50 fazia referência ao "jornal encarregado da divulgação de atos oficiais" (o revogado artigo $3^{\circ}$, inciso III), o que em nada se difere da nova regra. A novidade está no final do novo dispositivo, que concede gratuidade apenas se houver dispensa de publicação em outros meios. Em outras palavras, se for necessária a publicação em um jornal de grande circulação, por exemplo, não há gratuidade já que envolve o uso de meio de iniciativa privada. Afinal, o Estado não pode obrigar o particular a realizar gratuitamente qualquer atividade senão por preceito constitucional, por ferir o princípio da livre iniciativa, fundamento da República, esculpido nos artigos $1^{\circ}$, inciso IV e 170.

Já no inciso IV há a previsão de gratuidade quanto a indenização devida à testemunha que, quando empregada, receberá do empregador salário integral, como se em serviço estivesse. A modificação realizada pelo legislador em comparação com a Lei nº 1.060/50 é que não há mais previsão de direito de regresso contra o Poder Público. Desse modo, em consonância com o artigo 822 da Consolidação das Leis do Trabalho que impede qualquer desconto pela falta ao serviço em razão do comparecimento para depor, não há mais como o empregador cobrar do Estado o valor respectivo do tempo de serviço que o empregado deixou de realizar.

No inciso V há a repetição da regra de outrora que concede gratuidade nas despesas com a realização de exame de DNA. As diferenças residem na abertura para outros procedimentos

ato administrativo do próprio tribunal instituiu a taxa de desarquivamento dos autos. Em ação promovida pela Associação dos Advogados de São Paulo, a inconstitucionalidade foi reconhecida o que teve como efeito a impossibilidade de sua cobrança. Diante da situação, a Assembleia Legislativa do Estado de São Paulo alterou o texto da Lei Estadual $n^{\circ} 11.608 / 03$, na tentativa de restabelecer a taxa de desarquivamento dos autos, indicando que o Órgão Especial do Tribunal de Justiça de São Paulo teria competência para fixar os valores. Novamente, a norma foi considerada inconstitucional e, até o ano corrente, não há em São Paulo a cobrança da taxa de desarquivamento dos autos. Situação semelhante também ocorreu com o Tribunal Regional Federal da $3^{\mathrm{a}}, 4^{\mathrm{a}}$ e $5^{\mathrm{a}}$ Regiões. 
além da investigação de maternidade ou paternidade e no benefício para outros exames que possam ser considerados essenciais para o deslinde da causa.

Trata o inciso VI dos honorários do advogado e do perito e a remuneração do intérprete ou do tradutor nomeado para apresentação de versão em português de documento redigido em língua estrangeira. Antes, na Lei no 1.060/50 não havia previsão de gratuidade para o trabalho do tradutor, apesar de ser possível a interpretação extensiva do vocábulo "perito" para incluir os tradutores. De qualquer maneira, o Código de Processo Civil explicitou o benefício para o resultado do trabalho desses profissionais.

O inciso VII é uma novidade. A gratuidade de justiça compreende também o custo com a elaboração de memória de cálculo, quando exigida para instauração da execução. Neste diapasão, o serviço de contador judicial ou experto que elabore o detalhamento dos cálculos efetuados para se chegar ao valor a ser cobrado na execução é igualmente gratuito para os beneficiários da justiça gratuita.

O inciso VIII concede gratuidade para os depósitos previstos em lei para interposição de recurso, para propositura de ação e para a prática de outros atos processuais inerentes ao exercício da ampla defesa e do contraditório. Hipótese já prevista na Lei no 1.060/50, é decorrência lógica que os valores envolvidos para a realização de tais atos processuais estejam submetidos à gratuidade.

A última hipótese de gratuidade está contida no inciso IX, também uma novidade do Código de Processo Civil. Aduz que são gratuitos ao beneficiário os emolumentos devidos a notários ou registradores em decorrência da prática de registro, averbação ou qualquer outro ato notarial necessário à efetivação de decisão judicial ou à continuidade de processo judicial no qual o benefício tenha sido concedido ${ }^{21}$. A leitura do enunciado demanda atenção, haja vista que não são quaisquer atos notariais que estão abrangidos, mas somente aqueles que são

\footnotetext{
${ }^{21}$ Importante lembrar que as escrituras públicas de divórcio e separação consensuais, de inventário e de partilha já poderiam ser gratuitas para os que se declarassem pobres, consoante as Leis $\mathrm{n}^{\text {o }} 11.441 / 07$ e $11.965 / 09$ e a Resolução no 35/2007 do CNJ.
} 
imprescindíveis para a efetivação de determinação judicial ou para dar encaminhamento à demanda que já tenha reconhecido o direito à gratuidade de justiça ${ }^{22}$.

Emolumentos são valores entregues às serventias extrajudiciais, isto é, as retribuições devidas pelo exercício de um cargo ou ofício, cuja natureza é de taxa. Tem, pois, natureza de tributo. Eles serão custeados no caso de gratuidade de justiça pelos recursos alocados no orçamento do respectivo ente público, não podendo serem utilizados os recursos do fundo de custeio da Defensoria Pública, conforme artigo 95, parágrafos $3^{\circ}$ a $5^{\circ}$ com leitura combinada com o do artigo 98, parágrafo $7^{\circ}$, ambos do Código de Processo Civil.

O diploma processual, em seu artigo 98, parágrafo $8^{\circ}$ também disciplinou o caso de haver dúvida do notário ou registrador sobre o preenchimento dos pressupostos para concessão da gratuidade de justiça. Se ocorrer, a serventia extrajudicial deverá praticar o ato mesmo assim, mas poderá requerer ao juízo competente das questões notariais ou registrais a revogação total ou parcial do benefício, bem como o parcelamento dos valores devidos. Havendo tal requerimento, o beneficiário será citado no procedimento de dúvida para, em quinze dias, se manifestar, justificando o seu pleito de gratuidade ou concordando com os termos exarados pelo notário ou registrador.

Assim como pode ser sugerido no caso do inciso IX, o juiz não está adstrito a conceder totalmente ou a negar o pedido de gratuidade de justiça. É possível que ele adapte o benefício conforme a necessidade da parte hipossuficiente. Desse modo, os parágrafos $5^{\circ}$ e $6^{\circ}$ do artigo 98 do Código de Processo Civil concedem ao juiz o poder de determinar a gratuidade a somente alguns atos processuais, reduzir percentualmente o valor das despesas ou conceder parcelamento daquilo que o beneficiário tiver que adiantar no curso do procedimento.

Não há no Código de Processo Civil critérios de como tais medidas devem ser tomadas. Inexiste, por exemplo, qual o percentual mínimo e máximo de redução ou o número de parcelas mínimo e máximo que o juiz pode determinar. Enquanto por um lado a ausência de especificação enseja uma decisão particularizada conforme a necessidade, por outro causa

\footnotetext{
${ }^{22}$ Tanto a Constituição Federal quanto a Lei $\mathrm{n}^{\circ}$ 6.015/73 (Lei de Registros Públicos) preveem hipóteses de gratuidade notarial. Naquela, são gratuitos aos reconhecidamente pobres o registro civil de nascimento e a certidão de óbito (artigo $5^{\circ}$, inciso LXXVI) e, sem discriminação econômica, a celebração do casamento civil (artigo 226, parágrafo $1^{\circ}$ ). Nesta, além de reforçar o mandamento constitucional de gratuidade do registro civil de nascimento e do assento de óbito, amplia a gratuidade para a primeira certidão respectiva (artigo 30).
} 
insegurança jurídica porque cada magistrado poderá adotar um critério distinto para efetivar referidos dispositivos processuais.

Outras dificuldades também podem ser apontadas. É possível misturar as medidas como, à título exemplificativo, conceder gratuidade parcial e parcelada? Ou então, conceder gratuidade total para alguns atos e parcial para outros? Parece-nos que a resposta é afirmativa para ambas as questões, em festejo à adaptação da realidade processual à realidade das partes.

É preciso aguardar o fim do pagamento parcelado para a realização do ato processual? A resposta parece ser negativa somente quando houver medida urgente a ser praticada. Se não houver o pagamento das parcelas, o ato não é praticado; mas se foi urgente e já foi praticado, parece ser interessante a adoção adaptada da regra do parágrafo único do artigo 102 do Código de Processo Civil: caso seja o autor o responsável, o processo poderá ser extinto sem resolução de mérito. Se for réu ou terceiro, nenhuma outra diligência ou ato será deferido enquanto não houver o recolhimento.

Ainda que se cogite de soluções, tais respostas ainda são opinativas, pois todas não encontram respaldo expresso na lei. A pacificação e estabilização da jurisprudência para tais hipóteses dependerão de manifestação do Superior Tribunal de Justiça.

\section{O PROCEDIMENTO PARA OBTENÇÃO DA GRATUIDADE DE JUSTIÇA}

O Código de Processo Civil foi bastante maleável quanto aos momentos em que a parte poderá pleitear o benefício da gratuidade de justiça. No caso do autor, se a necessidade é preexistente ou concomitante à propositura da ação, deverá ser pleiteada na petição inicial. Se for superveniente, o pedido poderá ser formulado por petição simples durante o trâmite processual. À semelhança do autor funciona a regra para o réu: o pedido deverá ser feito na contestação se preexistente ou concomitante a esta a necessidade; se superveniente, também por petição simples. Na ocasião de haver intervenção de terceiro, na petição de ingresso deve constar o pedido de gratuidade se preexistente ou concomitante e em petição simples se superveniente. 
Não haverá incidente processual próprio para o processamento do pedido de gratuidade de justiça, ainda que seja superveniente. O artigo 99, parágrafo $1^{\circ}$ do Código de Processo Civil determina que deverá tramitar nos autos do próprio processo e não haverá suspensão do seu curso para a tomada de decisão.

Feito o pedido, o juiz o apreciará e decidirá pelo seu deferimento, parcial indeferimento ou indeferimento. No caso de parcial indeferimento, a gratuidade poderá ser concedida pelo magistrado apenas para alguns procedimentos ao invés de todos ou determinar percentagem ou parcelamento menor do que o pleiteado pela , conforme se extrai do parágrafo $5^{\circ}$ do artigo 98 do Código de Processo Civil.

O indeferimento só poderá ocorrer se houver nos autos elementos que evidenciem a falta dos pressupostos legais para a concessão de gratuidade de justiça. A norma jurídica, apesar de simples, apresenta um problema crucial: em nenhum momento o Código de Processo Civil apresenta explicitamente quais são os pressupostos legais para o benefício, em critérios objetivos $^{23}$. Assim, fica a cargo do juiz verificar diante do caso concreto, a partir das informações constantes no processo, se a parte efetivamente não possui recursos para as despesas judiciais.

A negativa ao benefício, entretanto, não poderá ser automática. O juiz é obrigado, de acordo com o artigo 99, parágrafo $2^{\circ}$ do Código de Processo Civil, determinar à parte a comprovação da sua condição de necessidade. Para tanto, deverá juntar ao processo documentos que comprovem tal situação, como holerites ou Declaração de Imposto de Renda. Todavia, não se deve esquecer que, se não houver elementos suficientes para a dúvida, o magistrado não poderá exigir comprovação complementar da pessoa física, haja vista ter ela presunção relativa de insuficiência de recursos se assim declarar, conforme visto anteriormente.

A jurisprudência traz casos curiosos de verificação de que a parte possui recursos suficientes para arcar com as despesas judiciais. Trazendo sinteticamente dois julgados para exemplificar, um juiz de Cerro Largo-RS negou o pedido de gratuidade de justiça de uma parte

\footnotetext{
${ }^{23}$ Para exemplificar um critério objetivo, a Defensoria Pública do Estado de São Paulo impõe de maneira geral que o beneficiário do serviço de assistência judiciária tenha renda familiar de até três salários mínimos mensais, podendo excepcionar esta regra diante da peculiaridade do caso concreto.
} 
por esta publicar fotos nas redes sociais ostentando objetos de alto valor ${ }^{24}$. O Tribunal Regional Federal da $4^{\mathrm{a}}$ Região revogou a gratuidade de justiça de uma parte por ter sido nomeada em concurso para o cargo de professor em uma universidade federal ${ }^{25}$.

Havendo deferimento do pedido de concessão de gratuidade de justiça, com efeitos $e x$ nunc desde o seu pleito ${ }^{26}$, a parte contrária poderá impugná-lo, apresentando provas de que a parte beneficiada possui recursos suficientes para arcar com as despesas judiciais, conforme o artigo 100 do Código de Processo Civil. Esta impugnação deverá ser realizada na contestação, na réplica ou nas contrarrazões de recurso, quando estiver dentro do prazo para protocolo de referidas peças. Caso o pedido seja superveniente ou formulado por terceiro interveniente, a impugnação poderá ser proposta por meio de petição simples, nos autos do próprio processo e sem suspensão de sua marcha.

O dispositivo legal aduz que o prazo para a impugnação por meio de petição simples é de 15 dias. Contudo, não esclarece qual o termo inicial de sua contagem. Poder-se-ia cogitar que o prazo é contado a partir do deferimento pelo magistrado da gratuidade de justiça pleiteada supervenientemente. Só que este entendimento apresenta um problema grave: e se a parte contrária descobre só após o prazo de 15 dias que o beneficiado possui recursos suficientes para arcar com as despesas judiciais? O Código de Processo Civil não traz uma devida solução.

E este problema pode ser apontado igualmente para os casos de contestação, réplica e contrarrazões que, apesar de terem termo inicial do prazo bem delimitado, podem padecer da mesma dificuldade de a parte só descobrir após o seu termo final ou da preclusão consumativa a real condição financeira do beneficiário. Neste sentido, ficaria a parte impossibilitada de impugnar a gratuidade de justiça indevidamente deferida.

\footnotetext{
${ }^{24}$ CONSULTOR JURÍDICO. Homem perde Justiça gratuita por publicar fotos de "boa fase" em redes sociais. Disponível em: https://www.conjur.com.br/2018-fev-18/homem-perde-justica-gratuita-fotos-publicadas-redessociais. Acesso em: 18/03/2018.

${ }^{25}$ CONSULTOR JURÍDICO. Professor perde assistência judicial gratuita porque foi nomeado em concurso. Disponível em: https://www.conjur.com.br/2017-out-22/nomeacao-concurso-afasta-assistencia-judicial-gratuita. Acesso em: 18/03/2018.

${ }^{26}$ A jurisprudência do Superior Tribunal de Justiça é pacífica no sentido de que o pedido de gratuidade de justiça não possui efeitos retroativos. Vide, por exemplo: BRASIL. Superior Tribunal de Justiça, $4^{\mathrm{a}}$ Turma. Agravo Regimental no Agravo em Recurso Especial nº 618.176/MS. Rel. Min. Raul Araújo, votação unânime, j. 05/05/2015.
} 
Por isso, parece que uma boa solução é compreender que, para o caso de pedido superveniente, os 15 dias de prazo sejam contados a partir da ciência inequívoca do impugnante sobre a situação econômica do impugnado. Se as provas da não hipossuficiência já estejam no processo, a contagem é mais fácil. Caso contrário, trata-se de prova de difícil produção, o que com certeza levaria a muitos indeferimentos das impugnações apresentadas.

Uma melhor solução para o caso de provas que não estejam no processo, que acaba por induzir à inocuidade do prazo de 15 dias neste contexto, é permitir que a qualquer tempo possa ser impugnada a gratuidade de justiça concedida, haja vista que o juiz tem o poder-dever de dirigir o processo reprimindo qualquer ato contrário à dignidade da justiça, além de determinar o suprimento de pressupostos processuais e o saneamento de outros vícios processuais (artigo 139, incisos III e IX do Código de Processo Civil). Assim, a impugnação acaba sendo um mero "aviso" ao juiz da inexistência de preenchimento dos pressupostos para a concessão da gratuidade de justiça, e este, por ato de ofício fundado no artigo 99, parágrafo $2^{\circ}$ do Código de Processo Civil, poderá revogá-la.

Então a regra seria a seguinte: se há pedido superveniente de gratuidade de justiça e as provas contra a hipossuficiência já estejam no processo, a parte contrária terá 15 dias para impugnar, contado este prazo do deferimento do benefício. Isto porque o deferimento se confunde com a ciência inequívoca sobre a circunstância econômica do beneficiado, haja vista que só se tornou prova relevante para tanto com a apreciação e admissão judicial da gratuidade. Por outro lado, se as provas são exógenas, não há contagem de prazo, bastando que o impugnante alerte fundamentadamente o juízo que, no exercício de seu poder instrutório, revogará a gratuidade de ofício.

No tocante à contestação, réplica e contrarrazões, a solução parece ser a mesma. O que muda é que para a primeira hipótese a parte contrária deverá impugnar em sua peça processual, no prazo estipulado para o seu protocolo.

Ainda assim, nota-se que mesmo no primeiro caso o juiz em seu poder instrutório poderá revogar o benefício ex officio quando tiver ciência da ausência de preenchimento dos pressupostos para a sua concessão. Por isso, em uma análise bastante objetiva e sintética, a gratuidade de justiça pode ser revogada a qualquer tempo pelo magistrado. 
Havendo a revogação, dispõe o artigo 100, parágrafo único do Código de Processo Civil que a parte deverá arcar com as despesas processuais que tiver deixado de adiantar. Caso não pague tempestivamente no prazo assinalado pelo juiz e não havendo recurso contra tal decisão, ocorrerá o seu trânsito em julgado e o resultado dependerá se aquele que pleiteou é autor ou réu. Se for autor, a solução é a extinção do processo sem resolução de mérito. Se for réu ou terceiro interveniente, não será deferida a realização de nenhum ato ou diligência requerida enquanto não efetuado o depósito (artigo 102 e seu parágrafo único do Código de Processo Civil).

Enquanto a consequência atribuída ao réu ou ao terceiro parece ser adequada, aquela atribuída ao autor merece maior atenção. Parece que o legislador neste ponto somente imaginou a concessão total de gratuidade de justiça para determinar o efeito de seu indeferimento, sem levar em consideração que ela pode ser concedida para um ato processual específico. Dessa maneira, em um caso que há revogação do benefício para um exame pericial concernente a apenas um dos vários pedidos não parece razoável a extinção de todo o processo. Por isso, a leitura adequada do dispositivo parece ser aquela que extingue somente o pedido sem resolução do mérito, e isto se a prova for essencial para a resolução da demanda. Se existirem outros elementos capazes de convencer o juízo, extinguir o pedido parece ser medida contrária ao dever de cooperação e à obtenção de uma decisão de mérito justa e efetiva, conforme esculpido no artigo $6^{\circ}$ do Código de Processo Civil.

O parágrafo único do artigo 100 do Código de Processo Civil também impõe que a parte que pleitear a gratuidade de justiça de má-fé, ou seja, intencionalmente ocultando ter recursos suficientes para arcar com as despesas judiciais, deverá pagar até o décuplo de seu valor a título de multa, que será revertida em benefício da Fazenda Pública estadual ou federal e poderá ser inscrita em dívida ativa. Assim, a multa se desdobrará em dívida fiscal que poderá ser cobrada pela Fazenda Pública posteriormente por meio de uma ação de execução fiscal regulada pela Lei nº 6.830/80 (Lei de Execução Fiscal).

Esta má-fé, todavia, não pode ser confundida com a condenação por litigância de máfé. A primeira se refere ao pedido de gratuidade em si, indevido. A segunda, por sua vez, às 
hipóteses previstas no artigo 80 do Código de Processo Civil ${ }^{27}$, que acarretará em favor da parte contrária em multa superior a $1 \%$ e inferior a $10 \%$ do valor corrigido da causa (podendo ser majorada em até dez vezes o valor do salário mínimo se o valor da causa for irrisório ou inestimável), honorários advocatícios, perdas e danos e todas as despesas efetuadas por esta no processo (artigo 81 do Código de Processo Civil).

Tanto são situações distintas que o Superior Tribunal de Justiça ${ }^{28}$ já decidiu que a condenação por litigância de má-fé não implica em revogação da gratuidade de justiça. Conforme referido tribunal, as sanções para a litigância de má-fé integram um rol taxativo, não admitindo ampliação pelo intérprete.

Contra o indeferimento ou a revogação cabe recurso. Consoante o artigo 101 do Código de Processo Civil, se a decisão que indeferir ou revogar for interlocutória, caberá o recurso de agravo de instrumento (regra reforçada pelo artigo 1.015, inciso V do Código de Processo Civil). No entanto, se uma destas hipóteses ocorrer na sentença, então caberá o recurso de apelação. Os parágrafos $1^{\circ}$ e $2^{\circ}$ dizem respeito somente ao recurso de apelação, não ficando isto claro na organização do dispositivo e na sua redação. Neles, é previsto que o recorrente está dispensado de recolher as custas até que o relator decida sobre a gratuidade de justiça antes do mérito do recurso, caso ele trate também de outros temas. Se a denegação ou revogação for confirmada, o relator ou o órgão colegiado determinará ao recorrente o recolhimento das custas processuais, no prazo de 5 dias, sob pena de não conhecimento do recurso.

O Código de Processo Civil não disciplinou hipótese de cabimento de recurso contra a denegação da impugnação à gratuidade de justiça. De acordo com o que argumenta Trindade ${ }^{29}$, trata-se de desequilíbrio processual inaceitável, mas que é facilmente resolvido mediante o uso da interpretação conforme a Constituição: admite-se a mesma espécie recursal contra o indeferimento da impugnação que caberia ao indeferimento ou revogação da gratuidade de

\footnotetext{
${ }^{27}$ Art. 80. Considera-se litigante de má-fé aquele que: I - deduzir pretensão ou defesa contra texto expresso de lei ou fato incontroverso; II - alterar a verdade dos fatos; III - usar do processo para conseguir objetivo ilegal; IV opuser resistência injustificada ao andamento do processo; $\mathrm{V}$ - proceder de modo temerário em qualquer incidente ou ato do processo; VI - provocar incidente manifestamente infundado; VII - interpuser recurso com intuito manifestamente protelatório.

${ }^{28}$ BRASIL. Superior Tribunal de Justiça, $3^{\mathrm{a}}$ Turma. Recurso Especial no 1.663.193/RN. Rel. Min. Nancy Andrighi, votação unânime, j. 20/02/2018.

${ }^{29}$ TRINDADE, André Karam. Art. 101. In: STRECK, Lenio Luiz; NUNES, Dierle; CUNHA, Leonardo (orgs.). Comentários ao Código de Processo Civil. São Paulo: Saraiva, 2016. p. 171.
} 
justiça. Assim, ao impugnante, tendo seu pleito negado, poderia se valer do recurso de agravo de instrumento ${ }^{30}$ se a negativa estiver contida em decisão interlocutória ou de apelação se estiver contida em sentença.

A gratuidade de justiça também pode ser pleiteada em grau recursal (artigo 99, parágrafo $7^{\circ}$ do Código de Processo Civil). Nesta hipótese, a parte estará dispensada de realizar o preparo e comprová-lo, isto é, de juntar aos autos o comprovante de pagamento da taxa judiciária e do porte de remessa e de retorno dos autos, salvo este último se os autos forem eletrônicos (artigo 1.007 do Código de Processo Civil). Repete-se a decorrência lógica: se o recorrente está pleiteando o benefício, ele não terá recursos para pagar as despesas recursais do processo. Por isso, este requisito de admissibilidade do recurso deve ser afastado.

Feito o pedido, o relator do recurso deverá apreciar o requerimento. Se houver deferimento, o recurso será processado normalmente. Caso contrário, o relator deverá fixar um prazo para que o recorrente realize o recolhimento, em observância do artigo 99, parágrafo $7^{\circ}$ do Código de Processo Civil.

\section{CONCLUSÃO}

O Código de Processo Civil não é perfeito e não traz solução para todos os conflitos que porventura surgirão na prática forense. Neste diapasão, buscou-se apontar respostas para tais casos em consonância com os objetivos e valores presentes na Constituição Federal e nas demais normas infraconstitucionais atinentes ao tema, sem ignorar as orientações jurisprudenciais já consolidadas.

Diante de todo o exposto, percebe-se que a previsão de regras específicas sobre a gratuidade de justiça no Código de Processo Civil representa um grande avanço no tratamento

\footnotetext{
${ }^{30}$ Vale lembrar que, embora majoritariamente se entenda que o rol do artigo 1.015 do Código de Processo Civil seja taxativo, o próprio Superior Tribunal de Justiça já admitiu hipótese não prevista, ao entender cabível o recurso contra decisão que reconhece a incompetência do juízo (BRASIL. Superior Tribunal de Justiça, 4a Turma. Recurso Especial no 1.679.909/RS. Rel. Min. Luis Felipe Salomão, votação unânime, j. 14/11/2017).
} 
da matéria. Há um acréscimo significativo na segurança jurídica, estabilidade e previsibilidade das decisões, que têm um suporte legislativo consistente para o deferimento ou não dos pleitos. Com isso, espera-se que haja uma diminuição drástica nas decisões conflitantes, tão comuns quando da mera vigência da Lei $\mathrm{n}^{\circ} 1.060 / 50$ que, como foi visto, em breve perderá totalmente a relevância como norma regulamentadora da gratuidade de justiça e das assistências jurídica e judiciária.

\section{REFERÊNCIAS BIBLIOGRÁFICAS}

BARBOSA, Ruy Pereira. Assistência jurídica. Rio de Janeiro: Forense, 1998.

BRASIL. Superior Tribunal de Justiça, $1^{\text {a }}$ Turma. Recurso Especial no 1.082.376/RN. Rel. Min. Luiz Fux, votação unânime, j. 17/02/2009.

Superior Tribunal de Justiça. $2^{\text {a }}$ Turma. Recurso Especial nº 1.138.072/MG. Rel. Min. Castro Meira, votação unânime, j. 01/03/2011.

. Superior Tribunal de Justiça, $6^{a}$ Turma. Habeas Corpus nº 217.657/SP. Rel. Min. Vasco

Della Giustina (Desembargador convocado do TJ/RS), votação unânime, j. 02/02/2012.

Superior Tribunal de Justiça, $6^{\mathrm{a}}$ Turma. Habeas Corpus nº 218.570/SP. Rel. Min. Maria Thereza de Assis Moura, votação unânime, j. 16/02/2012.

Superior Tribunal de Justiça, $1^{\text {a }}$ Turma. Agravo Regimental no Agravo em Recurso Especial nº 556.355/MG. Rel. Min. Sérgio Kukina, votação unânime, j. 10/02/2015.

Superior Tribunal de Justiça, Corte Especial. Embargos de Divergência em Agravo em

Recurso Especial n 86.915/SP. Rel. Min. Raul Araújo, votação unânime, j. 26/02/2015.

Superior Tribunal de Justiça, $4^{\mathrm{a}}$ Turma. Agravo Regimental no Agravo em Recurso Especial nº 618.176/MS. Rel. Min. Raul Araújo, votação unânime, j. 05/05/2015. 
Superior Tribunal de Justiça, $4^{\mathrm{a}}$ Turma. Recurso Especial ${ }^{\circ}$ 1.679.909/RS. Rel. Min. Luis Felipe Salomão, votação unânime, j. 14/11/2017.

. Superior Tribunal de Justiça, $1^{\text {a }}$ Turma. Agravo Interno no Agravo em Recurso Especial $n^{\circ}$ 525.359/MS. Rel. Min. Gurgel de Faria, votação unânime, j. 06/02/2018.

Superior Tribunal de Justiça, $3^{\mathrm{a}}$ Turma. Recurso Especial no 1.663.193/RN. Rel. Min. Nancy Andrighi, votação unânime, j. 20/02/2018.

Superior Tribunal de Justiça, $3^{\mathrm{a}}$ Turma. Agravo Interno no Agravo em Recurso Especial nº 1.140.206/RS. Rel. Min. Ricardo Villas Bôas Cueva, votação unânime, j. 27/02/2018.

. Superior Tribunal de Justiça, $3^{\text {a }}$ Turma. Agravo Interno no Agravo em Recurso Especial nº 1.131.308/RS. Rel. Min. Paulo de Tarso Sanseverino, votação unânime, j. 27/02/2018.

Supremo Tribunal Federal. Habeas Corpus no 70.514/RS. Rel. Min. Sydney Sanches, votação por maioria, j. 23/03/1994.

Supremo Tribunal Federal. Recurso Extraordinário no 135.328/SP. Rel. Min. Marco Aurélio, votação unânime, j. 29/06/1994.

Supremo Tribunal Federal. Recurso Extraordinário nº 147.776/SP. Rel. Min. Sepúlveda Pertence, votação unânime, j. 29/06/1998.

Supremo Tribunal Federal, $2^{\mathrm{a}}$ Turma. Agravo Regimental no Recurso Extraordinário $\mathrm{n}^{\circ}$ 550.202. Rel. Min. Cezar Peluso, votação unânime, j. 11/03/2008.

Supremo Tribunal Federal, $1^{\text {a }}$ Turma. Agravo Regimental no Agravo de Instrumento $\mathrm{n}^{\circ}$ 580.880. Rel. Min. Menezes Direito, votação unânime, j. 07/04/2009.

CONSULTOR JURÍDICO. Homem perde Justiça gratuita por publicar fotos de "boa fase" em redes sociais. Disponível em: https://www.conjur.com.br/2018-fev-18/homem-perde-justicagratuita-fotos-publicadas-redes-sociais. Acesso em: 18/03/2018. 
. Professor perde assistência judicial gratuita porque foi nomeado em concurso. Disponível em: https://www.conjur.com.br/2017-out-22/nomeacao-concurso-afastaassistencia-judicial-gratuita. Acesso em: 18/03/2018.

DIDIER JR., Fredie; OLIVEIRA, Rafael. Benefício da justiça gratuita. Salvador: Juspodivm, 2008.

ESTEVES, Diogo; SILVA, Franklyn Roger Alves. Princípios Institucionais da Defensoria Pública. Rio de Janeiro: Forense, 2014.

GIANNAKOS, Angelo Maraninchi. Assistência Judiciária no Direito Brasileiro. Porto Alegre: Livraria do Advogado, 2008.

LIMA, Frederico Rodrigues Viana de. Defensoria Pública. Salvador: Juspodivm, 2010.

MIRANDA, Francisco Cavalcanti Pontes de. Comentários ao Código de Processo Civil: tomo I. Rio de Janeiro: Forense, 1958.

STRECK, Lenio Luiz; NUNES, Dierle; CUNHA, Leonardo (orgs.). Comentários ao Código de Processo Civil. São Paulo: Saraiva, 2016.

Data de submissão: 27/08/2019

Data de Aceite: 05/12/2019 